OLSEN, E. (1951). J. gen Microbiol. 5, 817-829.

\title{
The Fermentation of Sugar-Beet Pulp Silage
}

\author{
By THE LATE E. OLSEN \\ The Danish Sugar Factories Ltd., Central Laboratory, Copenhagen
}

\begin{abstract}
SUMMARY : An investigation was made of the processes occurring during the ensiling of sugar-beet pulp. Pulp was enclosed in rubber bags buried in a silo to obtain the same conditions of pressure and temperature as prevail in the silo itself. An outlet from the bags was provided for the measurement of evolved gases and seepage. Pulp alone was compared with pulp $+4 \%$ molasses. The process was followed by withdrawing bags at short intervals, and making bacteriological and chemical examinations of the contents.

The addition of molasses resulted in a pure lactic acid fermentation of the sucrose with very small losses in dry matter. Few butyric acid bacteria were found. Where molasses was not added a vigorous butyric acid fermentation of hexosans and pentosans occurred, resulting in 12-15\% loss of dry matter due to seepage and formation of $\mathrm{CO}_{2}$, the number of butyric acid bacteria rising to $10^{9}-10^{10} / \mathrm{g}$. silage.

The initial flora of lactic bacteria consisted of Betacoccus arabinosaceus Orla Jensen, which was soon displaced by Streptobacterium plantarum and $\boldsymbol{S}$. casei Orla Jensen. After 2-3 months only Betabacterium breve Orla Jensen was found.
\end{abstract}

Sugar-beet pulp is a valuable by-product from the manufacture of beet sugar. It is poor in nitrogen (10\% total protein in the dry matter), but is an easily digestible and rather energy-rich feed when used in addition to protein-rich feeding stuffs or to the grass ration in summer; $1 \mathrm{~kg}$. dry matter has a feeding value of about one feeding-unit. In Denmark, where about a million metric tons of sugar-beet pulp are produced yearly, it has a value as feed of about 25 million Danish kroner. It is thus worth while studying the conservation of these large amounts of fodder and to find ways of decreasing losses during storage. The most rational method of conservation is drying because losses due to fermentation and seepage are then avoided, but in most countries this method is too expensive, costs amounting to $20-30 \%$ of the value of the pulp. Consequently in most countries pulp is conserved by ensiling.

Many experiments have been made to find the best ways to ensile beet pulp with the smallest possible losses. Most of these experiments have been conducted on a practical scale. Experiments by Steensberg (1945) showed that the addition of $2 \%\left(\mathrm{v} / \mathrm{v}\right.$ ) of $\mathrm{AIV}$-acid (equal parts of conc. $\mathrm{HCl}$ and conc. $\mathrm{H}_{2} \mathrm{SO}_{4}$ ) resulted in smaller losses and was slightly better than $1 \%$ of molasses, which gave about the same result as $2 \%$ formic acid (Amasil method).' It was also found that ensiling a mixture of pulp and beet tops resulted in greater losses than their separate ensiling. Similar results were obtained in experiments at Swedish sugar factories where it was also found that hard pressing of the pulp, (raising the dry weight to 14-16\%) gave better results than the ordinary pressing to $c .10 \%$ dry weight.

Jarl (1948) found that the digestibility of ensiled and dry pulp is about the same, although cellulose represents a greater part of the dry matter in the 
silage, and the feeding value of the dry matter of silage was greater than that of the dried pulp. Jarl (1948) also stated that the addition of 1, 2 or $3 \%$ molasses was as good as, or even better than, the use of AIV-acid. The costs are about the same, but molasses is much more convenient to handle during preparation of the silage, and it is not necessary to neutralize molasses silage before use, as is usually the case with the AIV-fodder. A rise of $0.2 \%$ in the fat content of milk was noted after feeding silage. It is possible, however, that the evaporation of organic acids and alcohols during the determination of 'dry matter', i.e. total weight minus water, was not duly taken into account. This error is often made in the determination of 'dry matter' in silage, which may thus appear to contain less potential foodstuff than is really the case. The products mentioned constitute a large part of the non-aqueous content and have a good food value. D-Lactic acid should be directly assimilable (Parnas, 1912) and L-lactic acid is excreted in the urine. Orla-Jensen, OrlaJensen \& Snog-Kjær (1948) pointed out that the calorific value of the sugar fermented is diminished only by one-third, through the formation of $\mathrm{D}$-lactic acid, by two-thirds when DL-lactic acid is formed, but if L-lactic acid only is formed the nutritive value of the sugar is completely lost. Acetic acid and ethanol are of rather high food value and may be transformed into fat, which possibly explains the higher percentage of fat in milk after feeding ensiled pulp.

The fermentation during the ensiling process is known to consist mainly of a lactic acid fermentation, usually accompanied by a butyric acid fermentation when little fermentable sugar is present. Detailed studies of the progress of the fermentation and of the balance between fermented material and products of fermentation are rare in the literature. It was the aim of the present work to follow changes in composition and bacterial flora and to account for the losses of dry matter during the preparation of silage from sugar-beet pulp.

\section{EXPERIMENTAL}

Rubber bags which could hold 9-10 kg. pulp were used as containers. At one end each bag was fitted with a hose of thinner rubber through which it could be filled with pulp. After filling, the hose was rolled up and tightly tied with string so that gas or juice could not escape. At the other end of each bag a piece of rubber tubing was attached by means of glass tubing to a long rubber tube which led gas and juice to a reservoir where the amounts could be measured and samples taken for analysis. These long rubber tubes were led through the silage inside iron pipes to avoid distortions resulting in blockage. The reservoirs for press juice (seepage) were Wulff flasks which allowed collection of juice while gas was either permitted to escape or was led to a 5 l. flask filled with a saturated aqueous solution of $\mathrm{NaCl}$, slightly acidified to diminish absorption of $\mathrm{CO}_{2}$. The amount of liquid expelled by gas was measured, and samples of gas taken for analysis.

After weighing, the bags were placed in the middle of a concrete silo about $3 \mathrm{~m}$. in depth and covered with tightly-packed pulp. This procedure was chosen in order to obtain the same conditions of pressure and temperature as those prevailing in an operating silo. 
In order to discern differences in fermentation when little sugar was present $(0 \cdot 3-0.5 \%$ of the pulp) as compared with the results when sufficient sugar for a pure lactic acid fermentation was present, pulp without any addition was compared with pulp+molasses $(4 \mathrm{~kg}$. molasses $/ 100 \mathrm{~kg}$. pulp). Before the addition of the molasses it was diluted with an equal weight of water.

The progress of fermentation was followed by withdrawing one bag of each type from the silo, initially every 2 or 3 days, and later less frequently. The contents of the bags were weighed, thoroughly mixed and samples taken, and at the same time the volumes of seepage in the Wulff flasks were measured and samples taken for analysis. When the silage itself was very moist, as was sometimes the case where no molasses was added, it was allowed to drain on a tray. It was considered that this 'drained-off juice' would have drained away from the silo and thus should be added to the seepage in the Wulff flasks to account for the total loss of material through seepage. Because the aim was to find out what happens during the fermentation proper, the amounts of the different substances in the seepage were added to the contents of the bags in the calculation of results, thus excluding factors other than the fermentation itself. The results of these calculations are shown in Figs. 3 and 4, while Table 5 shows the total losses of 'dry matter' due to fermentation and seepage.

\section{Analytical methods}

Bacteriological examination. Plating on Bacto-Tryptone glucose agar $+1 \%$. sucrose with incubation for 5 days at $30^{\circ}$ was used to identify betacocci (Leuconostoc) by the formation of dextran. After counting the plates, representative colonies were picked for later identification.

For the determination of butyric acid bacteria a series of dilutions ranging from $10^{-3}$ to $10^{-11}$ were inoculated into tubes of barley mash medium. The presence of butyric acid bacteria was detected by gas formation and the odour of butyric acid. The same procedure was used to determine the numbers of viable spores after pasteurization of the bacterial suspension at $80^{\circ}$ for $10 \mathrm{~min}$. This method was chosen because plating under anaerobic conditions or inoculation in deep agar tubes usually gave too small numbers.

Chemical analysis. As time did not permit an immediate complete analysis, 500 g. samples from the bags were given a preliminary drying at $70-80^{\circ}$ and later analysed for: 'dry matter' (drying at $105^{\circ}$ ); ash (as sulphate); total $\mathbf{N}$ (Kjeldahl), protein being calculated by multiplication by 6.25 ; cellulose (Scharrer \& Kürschner, 1931); pentosan (Kullgren \& Tydén, 1929); galacturonic acid (Sloep, 1928).

Pentosans are determined in the method of Kullgren \& Tydén (1929) as furfural after boiling and distillation with $\mathrm{HCl}$. By this procedure galacturonic acid is also transformed into furfural $+\left(\mathrm{CO}_{2}\right.$ and $\left.\mathrm{H}_{2} \mathrm{O}\right)$. It was therefore considered necessary to correct the 'pentosans' for galacturonic acid, as estimated by the amount of $\mathrm{CO}_{2}$ liberated by boiling with $\mathrm{HCl}$ (Sloep, 1928). In our hands this analysis did not give reproducible results; relative differences of c. $10 \%$ were often found. In the analytical results shown later 'pentosan' therefore means the sum of pentosan proper + galacturonic acid. But from the 
analysis it may be concluded that the pentosans account for $c .40 \%$ of the furfural-yielding substances, i.e. about $9 \%$ of pulp 'dry matter'. As to losses of 'pentosan' it may be assumed that they apply to the real pentosans only, as galacturonic acid is hardly fermented.

Analyses of juice squeezed from silage. This was analysed for: $p H$ value (glass electrode); titration figure (the figures obtained did not correlate well with the real amounts of acid, probably depending on the buffer content of the pulp); sucrose (Spengler, Tödt \& Scheuer, 1936), after inversion with $\mathrm{HCl}$, the values obtained of course include other substances capable of reducing Fehling's solution; ammonia (Folin, 1902). Organic acids; juice was acidified $\left(\mathrm{H}_{2} \mathrm{SO}_{4}\right)$ and extracted with a measured volume of ethyl ether in a flask. According to the partition principle a certain percentage of each acid is taken up by the ether, from which the acids were separated by shaking with dilute $\mathrm{NaOH}$. The alkaline aqueous phase was acidified, and volatile acids distilled off and determined by the method of Osburn, Wood \& Werkman (1936). In the residue from this distillation, lactic acid was determined after Szeberěnyi's (1917) method (oxidation to acetic acid and subsequent distillation and titration). In this way the troublesome preparation of Schenk filtrates was avoided, and the results were reliable (detailed description of methods, Olsen, 1949). Alcohols were determined by a modification of the methods of van der Lek (1930) and of Enebo (1943) (see Olsen, 1949); by means of chromicsulphuric acid, ethanol was oxidized to acetic acid and butanol to a mixture of acetic and butyric acids which were distilled off and analysed as above.

Seepage and drained-off juice were examined in the same way, and in addition dry matter, nitrogen, ash and pentosan were determined.

In the calculation of results account must be taken of the volatile substances which disappear during drying of samples, otherwise the determination of 'dry matter', i.e. total matter minus water, gives values which are too low. Experiment showed that when silage was dried at $105^{\circ}$ about $50 \%$ of the lactic, $90 \%$ of the acetic, and $80 \%$ of the butyric acids and the alcohols disappeared. By drying at $70-80^{\circ}, 15 \%$ of the lactic acid disappeared while the volatile acids and alcohols behaved as at $105^{\circ}$. When juices were dried at $105^{\circ}$ all the acids disappeared completely. Thus it was necessary to know the amounts of these volatile substances before calculating the real percentage of 'dry-matter', i.e. total matter minus water.

When the volatile substances mentioned were summed up there still remained a considerable part of 'dry matter' to be accounted for. This consisted mainly of hexosans, i.e. the remainder of the hemicelluloses, the pentosans having been determined directly. The hexosans were calculated by subtracting the sum of the percentages of the substances determined from 100, the difference thus giving approximately the percentage of hexosan.

In experiments where molasses was added sucrose disappeared with surprising rapidity, and the amount could not all be accounted for by the acids formed. But when the sum (sucrose + hexosan) was calculated, a much better correlation was found between the decrease of this quantity and acid production. No explanation is offered for this, but as in a sense sucrose forms 
part of the hexosans it is included subsequently in 'hexosan', the results of the direct sucrose determinations being also shown separately.

After the conclusion of fermentation there was still some 'sucrose' in the silage. It amounted to $1 \frac{1}{2}-2 \%$ of the 'dry matter' in experiments without molasses and to $c . \mathbf{0 . 4} \%$ when molasses had been added. Obviously we were here dealing with substances other than sugar capable of reducing Fehling's solution and which were largely formed during the fermentation, e.g. 2,3butanediol and acetoin. The greater formation of these substances from pulp alone than from pulp + molasses undoubtedly depended on the fact that the fermentation without added molasses was more heterogeneous than in its presence.

\section{RESULTS}

Two series of experiments were made, and although the fermentation was more vigorous in the second than in the first, the sequence of events was so nearly the same that it is safe to regard them as identical. In the following description therefore, in the main, the second experiment is reported. Good agreement was found between the amounts of carbohydrate fermented and acids, alcohols and $\mathrm{CO}_{2}$ formed.

The temperature in the silo itself was read daily from a maximum thermometer placed in an iron pipe inserted into the silage; readings were taken from 25 November to 31 January (Fig. 1). After an initial fall the temperature rose a few degrees, presumably as a consequence of heat generated by fermentation. In view of the vigour of the fermentation it might have been expected that the temperature would have risen more, but pulp containing $c .90 \%$ water has a high heat capacity. After about 9 days the temperature fell steadily reaching only about $10^{\circ}$ after 50 days, in spite of the low air temperature in January.

The gas production (Fig. 2), due to the activity of butyric acid bacteria, was evidently strongly suppressed by adding molasses. In the first experiment only $\mathrm{CO}_{2}$ and $\mathrm{H}_{2}$ were found, but in the second experiment unexplained trouble was encountered in determining $\mathrm{H}_{2}$; the combustion was very slow and resulted in too high figures. Only traces of $\mathrm{CO}_{2}$ were formed by the combustion, indicating probably traces of methane (3-5\% of total gas volume). Owing to these difficulties only the $\mathrm{CO}_{2}$-content of the gases in the second experiment is shown in Table 1 .

Table 1. Carbon dioxide production from pulp with and without added molasses after different times of fermentation

\begin{tabular}{|c|c|c|c|c|c|}
\hline \multirow[b]{2}{*}{ Addition to pulp } & \multicolumn{5}{|c|}{ Time after beginning experiment (days) } \\
\hline & 5 & 8 & 12 & 18 & 12 \\
\hline & \multicolumn{5}{|c|}{$\% \mathrm{CO}_{2}$ in evolved gas } \\
\hline None & - & 100 & 67. & $66 \cdot 4$ & - \\
\hline $4 \%$ molasses & $63 \cdot 5$ & $72 \cdot 5$ & 72 & $72 \cdot 1$ & $75 \cdot 5$ \\
\hline
\end{tabular}

In the second experiment the initial gas evolved was pure $\mathrm{CO}_{2}$ originating from the lactic acid fermentation. Later, when only very small volumes of gas 
were being evolved, some other gas $\left(\mathrm{H}_{2}\right.$ ?) was also present. Without molasses increasing amounts of $\mathrm{CO}_{2}$ were found, in agreement with the findings of Peterson \& Fred (1932) in acetone-butanol fermentations.

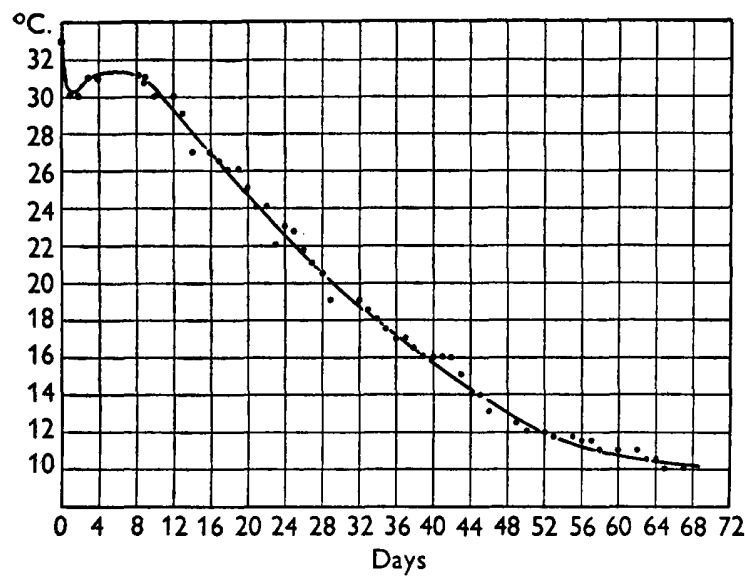

Fig. 1

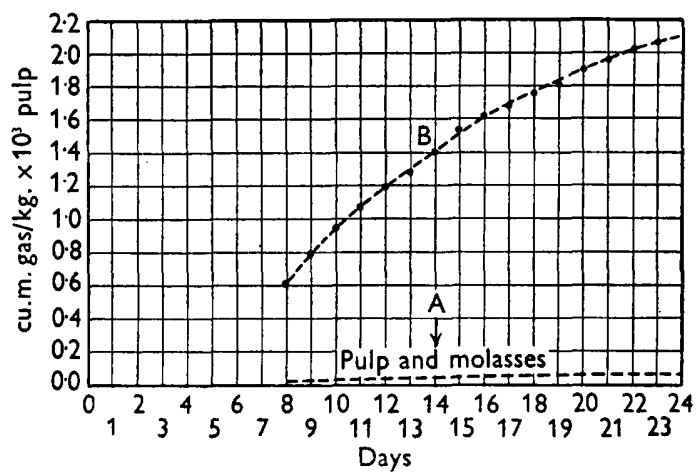

Fig. 2

Fig. 1. Temperature in the silo, 25 November - 31 January.

Fig. 2. Gas development from (A) pulp + molasses, (B) pulp alone.

\section{Bacteriology of the ensilage}

The percentage composition of the flora on the plates was estimated by the micro- and macroscopic appearance of the colonies, and a number of characteristic colonies were picked and identified. Lactic acid bacteria were predominant on the plates (butyric acid bacteria, of course, not being encountered on the aerobic plates). Sixty cultures were identified according to Orla-Jensen (1919), and were mainly rods, since the betacocci (Leuconostoc) usually give very characteristic mucoid colonies with sucrose present in the medium. All mucoid colonies were identified as Betacoccus arabinosaceus Orla-Jensen (Leuconostoc mesenteroides (Cienkowsky) van Tieghem).

The streptobacteria were an equal mixture of Streptobacterium casei and $S$. plantarum Orla-Jensen; no really clear distinction seems to exist between these two organisms. The betabacteria were Betabacterium breve Orla-Jensen. Yeasts were not encountered in any of the experiments.

All the strains of butyric acid bacteria isolated fermented lactose and lactate at pH 6.5 and 5.2. Van Beynum \& Pette (1935-6) stated that their species Clostridium tyrobutyricum fermented lactate but not lactose, while their $\mathrm{Cl}$. saccharobutyricum fermented lactose but not lactate. But many transition forms seem to exist; Richard (1948) found that ability to ferment these two substances was very variable within the same strain, and concluded that there was no reason for maintaining the species $\mathrm{Cl}$. tyrobutyricum van Beynum \& Pette. The strains here encountered may be identified as the common $\mathrm{Cl}$. butyricum Prazmowsky. 
The results of the bacteriological examinations are summarized in Table 2.

\section{Table 2. Results of bacteriological examination of samples of pulp taken during the course of the ensiling process}

$(+=$ pulp and molasses; $-=$ pulp alone. Butyric acid bacteria counts were determined by finding greatest dilution inoculated into barley mash medium which gave butyric fermentation. Spores were determined after pasteurizing at $80^{\circ}$ for $10 \mathrm{~min}$.)

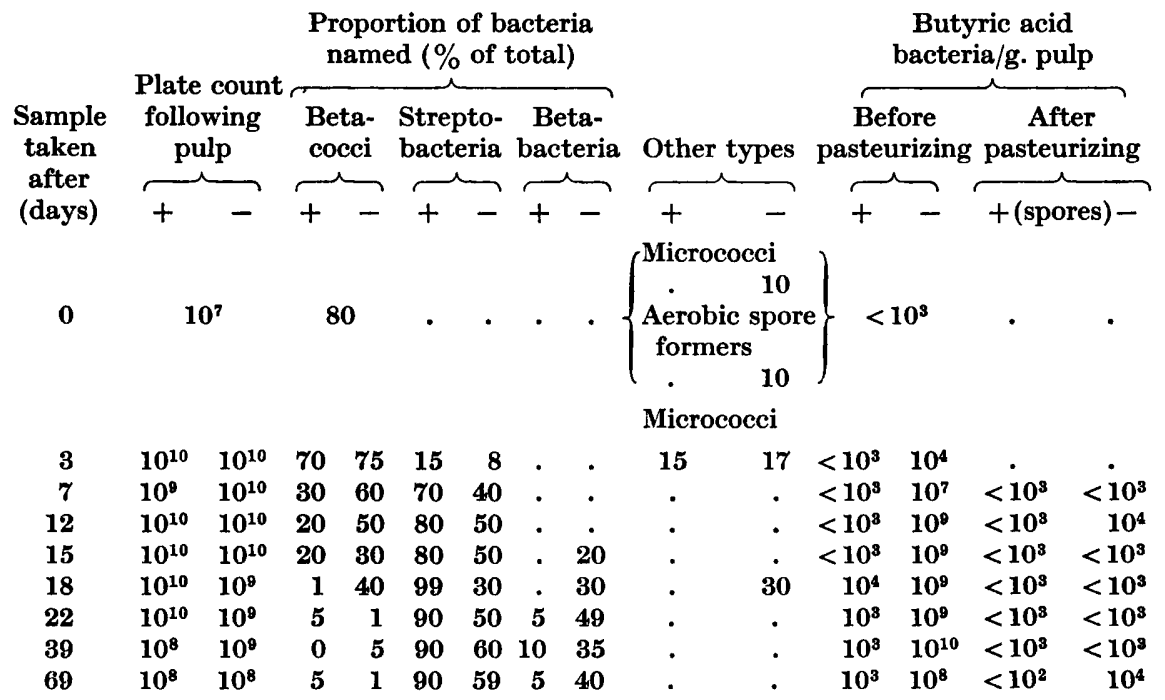

The original pulp contained betacocci and aerobic spore formers in appreciable amounts; rod-shaped lactic acid bacteria were not detected in the dilutions used. The betacocci multiplied rapidly, while the bacilli seemed completely suppressed. After 3 days streptobacteria appeared in measurable numbers, increasing steadily in the following days while the betacocci decreased. After c. 20 days the very acid-resistant betabacteria appeared, a little earlier in samples without molasses than in those with.

A very pronounced difference existed between pulps with and without molasses with regard to the butyric acid bacteria. With added molasses less than 1000 organisms/g. were found (highest dilution tested $10^{-3}$ ), but without molasses up to $10^{10}$ organisms/g. were found, the butyric acid bacteria here accounting for more than $50 \%$ of the total population. After storage in the silo for 4-5 months, the numbers of butyric acid bacteria diminished, as a consequence of low $\mathrm{pH}$ values and exhaustion of food. Very few spores were formed, possibly because the acid reaction checked spore formation.

In connexion with the suppression of butyric acid bacteria in silage made with molasses, it is worth mentioning that undissociated lactic acid exerts a specific bactericidal effect. This means that at decreasing $\mathrm{pH}$ values a given amount of this acid will show an increasing toxic action not found with inorganic acids at the same pH. At higher $\mathrm{pH}$ values larger amounts of the acid are required to obtain the same effect (Richard, 1947). In the silage+ 
molasses the $\mathrm{pH}$ value drops more rapidly and much larger amounts of lactic acid are formed than in silage without molasses (see later), probably explaining the difference in numbers of butyric acid bacteria in the two kinds of silage.

\section{Chemical changes during the silage process}

The chemical analyses of the second experiment only will be recorded, since no important differences were found between the two sets of experiments. The results are given in Figs. 3 and 4. As the aim was to give a picture of the fermentation proper, the results include possible losses in seepage and drainedoff juice (see later).

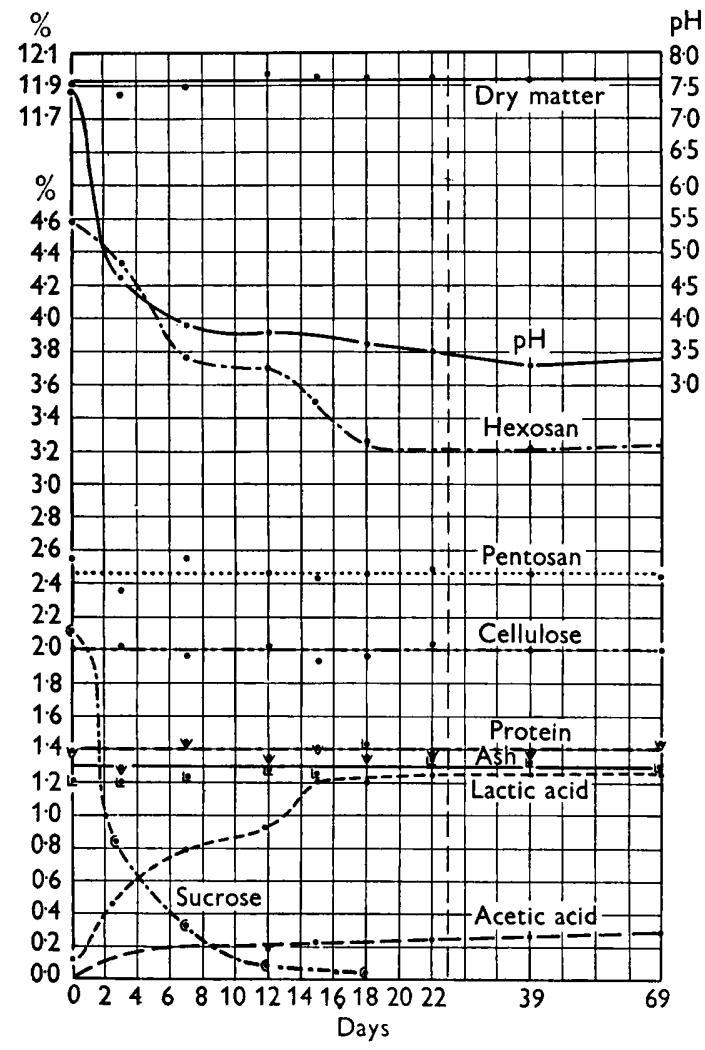

Fig. 3

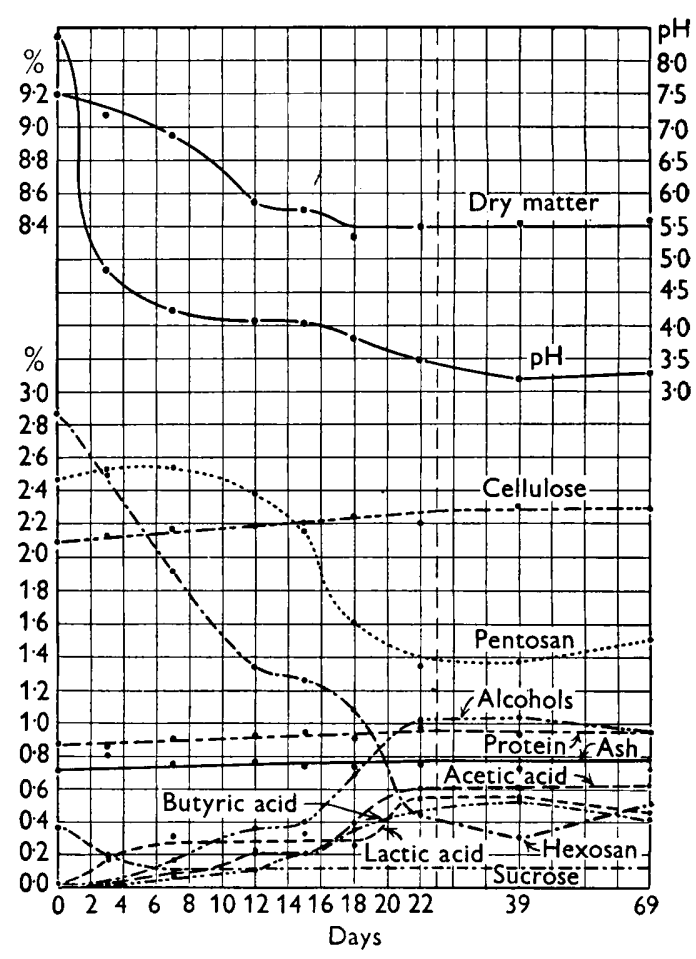

Fig. 4

Fig. 3. Experiment with pulp + molasses. $\mathrm{pH}$ values and percentage composition of the silage.

Fig. 4. Experiment with pulp alone. pH values and percentage composition of the silage.

Ensilage in presence of molasses. From the graph concerning the experiment with molasses the following conclusions may be drawn. A vigorous heterofermentative lactic acid fermentation begins almost at once. Only the 'hexosan' (sucrose + true hexosans) is subject to this fermentation, pentosan remaining almost unchanged during the whole experiment. Apparently only 
the sucrose part of the hexosan is attacked; at the start sucrose made up $30 \%$ of 'hexosan' and at the end of the experiment this had diminished by $30 \%$. But the direct determinations of sucrose are not concordant with the other results (cf. p. 820).

Concomitant with acid formation, the $\mathrm{pH}$ value rapidly decreased, and after 6 days reached $\mathrm{pH} 4 \cdot 0$, then decreasing slowly to about $3 \cdot 5$. The dry-matter content was unchanged throughout the whole period; pentosan, cellulose, protein and ash remained unchanged since they are not attacked by the lactic acid bacteria. The amount of ammonia was also constant throughout the experiment (50-70 mg./kg. silage).

The curves show a close correlation between the disappearance of hexosan and the formation of lactic and acetic acids. It seems characteristic that between the 6 th and 12 th days the fermentation ceased and then began again at a rapid rate; this was observed in both series of experiments. The explanation is probably to be found in the transition of the bacterial flora from the less acid-producing betacocci to the streptobacteria. From Table 2 it is seen that in the same period the betacocci diminished in numbers and probably formed no more acid, while the streptobacteria slowly became predominant, finally being found in numbers so large that a vigorous homofermentative fermentation resulted. The amount of acetic acid remained practically constant, and butyric acid and alcohols were not found. The appearance of the silage had not changed; it was firm with a pleasant acid odour.

Ensilage in absence of added molasses. In experiments without molasses the results were quite different. Here only $c .0 \cdot 4 \%$ sucrose was present at the beginning and this amount was not equivalent to the amount of acids formed so that other sources of carbohydrate must have been used. From Fig. 4 it is seen that true hexosan as well as pentosan was fermented; $c .90 \%$ of hexosan and $40 \%$ of the furfural-yielding substances (i.e. all the true pentosan) were used.

In the initial stage there was a heterofermentative lactic acid fermentation until the sucrose had been used up, then butyric acid fermentation began, coinciding with the increase in numbers of butyric acid bacteria (Table 2). This resulted in the formation of butyric and acetic acids, alcohols, $\mathrm{CO}_{2}$ and $\mathrm{H}_{2}$; acetone was not detected. In Fig. 4 the 'alcohol curve' includes total alcohol which actually consisted, on the average, of a mixture of $c .80 \%$ ethanol and $20 \%$ butanol.

Lactic acid was almost constant from the 6th until the 17th day, when a sudden rise occurred. The quantities of other fermentation products remained constant from the 12th to the 16th day and then rose rapidly, coinciding well with the changes in $\mathrm{pH}$ value, hexosan and pentosan content. The $\mathrm{pH}$ value fell at first rapidly to about $4 \cdot 2$, remaining constant until about the 16 th day when a new decrease occurred simultaneously with stronger acid formation (especially lactic acid).

The reason for this last decrease is probably to be found in a more vigorous breakdown of hemicelluloses making more pentose available. Betabacteria have a predilection for pentoses (arabinose); and by reference to Table 2 it is 
seen that, coincident with increase of lactic acid concentration, a considerable multiplication of betabacteria took place.

A loss of $8.3 \%$ of the original dry matter was found, very nearly accounted for by $\mathrm{CO}_{2}$ evolution. From Fig. 2 it is seen that gas development stopped when the loss of dry matter ceased. The $\mathrm{CO}_{2}$ output however did not account completely for the loss of dry matter, the reason presumably being the formation of small amounts of volatile substances such as 2,3-butanediol. As previously mentioned, reducing substances other than sugar were estimated in the determination of 'sucrose'. Without molasses about 5 times as much of these substances was found as in presence of molasses; therefore probably the greater part of these reducing substances were formed during the butyric acid fermentation.

Cellulose, protein and ash remained unchanged and, corresponding with the loss in dry matter, constitute an increasing percentage of the latter and of the silage itself. Pentosan also remained constant, indicating that its fermentation did not begin immediately, but only when the sucrose and apparently some of the hexosan proper had been fermented.

Fermentation was less intense in the sample taken at 69 days than in that at 39 days, resulting in smaller amounts of fermentation products, a larger residue of hexosan, higher $\mathrm{pH}$ value, and less gas evolution.

The appearance of the silage made without added molasses was very unpleasant even at an early stage; the original beet slices were hardly recognizable, the whole being a rather homogeneous, slimy, very moist mass with an unpleasant sharp smell of butyric and acetic acids. The volume of the pulp was then almost halved. The same picture is very often observed under practical conditions. The altered appearance of the pulp is, of course, due to the breakdown of hemicelluloses which ordinarily maintain its texture.

\section{Losses in seepage +drained-off juice}

In the results reported the amounts of the different substances in seepage and drained-off juice have been included in the calculation so as to give a picture of the fermentation proper. In actual practice the losses in seepage play an important role.

From Table 3 it is evident that seepage from the silage with molasses was more concentrated than from silage without molasses. Drained-off juice (juice allowed to drain off after removal of silage from rubber bag) was only found in the experiment without molasses. This type of juice was almost as concentrated as the seepage from pulp + molasses, owing to the large amounts of acids and alcohols.

The amounts of juice and the losses of dry matter in it are shown in Table 4, where it is seen that the pulp has not retained all the liquid added with the molasses ( $4 \%$ molasses $+4 \%$ water). Hence, where molasses was added, small amounts of seepage occurred at an early stage, resulting in small losses of 'dry matter'. During ensilage variable amounts of seepagte occurred; the loss of 'dry matter' at the end amounted to $2 \cdot 2 \%$ of the original. 
Table 3. Percentage composition of seepage and drained-off juice

\begin{tabular}{|c|c|c|c|}
\hline \multirow[b]{2}{*}{ Component } & \multirow[b]{2}{*}{$\begin{array}{c}\text { Pulp + molasses } \\
\text { In seepage } \\
(\%)\end{array}$} & \multicolumn{2}{|c|}{ Pulp alone } \\
\hline & & $\begin{array}{c}\text { In seepage } \\
(\%)\end{array}$ & $\begin{array}{l}\text { In drained-of } \\
\text { juice } \\
(\%)\end{array}$ \\
\hline Dry matter & 6.77 & 3.56 & $5 \cdot 60$ \\
\hline Ash & 0.67 & $0 \cdot 28$ & 0.65 \\
\hline Protein & 0.50 & $0 \cdot 10$ & 0.20 \\
\hline Pentosan & $0 \cdot 17$ & 0.95 & 0.79 \\
\hline Hexosan & $4 \cdot 35$ & $1 \cdot 13$ & 0.97 \\
\hline Lactic acid & 0.91 & 0.70 & 0.55 \\
\hline Acetic acid & $0 \cdot 17$ & $0 \cdot 17$ & $0 \cdot 68$ \\
\hline Butyric acid & . & $0 \cdot 03$ & 0.56 \\
\hline Alcohol & . & $0 \cdot 20$ & $1 \cdot 20$ \\
\hline
\end{tabular}

Table 4. Losses of 'dry matter' in seepage and drained-off juice from pulp alone or pulp and molasses

\begin{tabular}{|c|c|c|c|c|c|c|c|}
\hline \multirow[b]{3}{*}{$\begin{array}{l}\text { After } \\
\text { (days) }\end{array}$} & \multicolumn{3}{|c|}{ Pulp + molasses } & \multicolumn{4}{|c|}{ Pulp alone } \\
\hline & \multirow[b]{2}{*}{$\begin{array}{c}\text { Seepage } \\
\left(1 . / \mathrm{kg} \cdot \times 10^{3}\right)\end{array}$} & \multicolumn{2}{|c|}{ Loss of dry matter } & \multirow[b]{2}{*}{$\begin{array}{c}\text { Seepage } \\
\left(1 . / \mathrm{kg} \cdot \times 10^{3}\right)\end{array}$} & \multirow[b]{2}{*}{$\begin{array}{c}\text { Drainage } \\
\left(1 . / \mathrm{kg} \cdot \times 10^{3}\right)\end{array}$} & \multicolumn{2}{|c|}{ Loss of dry matter } \\
\hline & & $\left(\mathrm{kg} . / \mathrm{kg} . \times 10^{3}\right)$ & $\begin{array}{c}\text { Per- } \\
\text { centage of } \\
\text { original }\end{array}$ & & & $\left(\mathrm{kg} . / \mathrm{kg} . \times 10^{3}\right)$ & $\begin{array}{c}\text { Per- } \\
\text { centage of } \\
\text { original }\end{array}$ \\
\hline $\mathbf{3}$ & 0 & 0 & 0 & $\mathbf{0}$ & $\mathbf{0}$ & $\mathbf{0}$ & $\mathbf{0}$ \\
\hline 7 & 16 & $1 \cdot 1$ & 0.9 & $\mathbf{0}$ & 0 & $\mathbf{0}$ & $\mathbf{0}$ \\
\hline 12 & 16 & $1 \cdot 1$ & $0 \cdot 9$ & $\mathbf{0}$ & 0 & $\mathbf{0}$ & $\mathbf{0}$ \\
\hline 15 & 18 & 1.2 & $1 \cdot 0$ & 21 & 0 & 0.8 & 0.9 \\
\hline 18 & $\mathbf{0}$ & $\mathbf{0}$ & 0 & 71 & 0 & $2 \cdot 5$ & $2 \cdot 7$ \\
\hline 22 & $\mathbf{3 3}$ & $\mathbf{2 \cdot 2}$ & 1.8 & 75 & 68 & 6.5 & $7 \cdot 1$ \\
\hline 39 & 12 & $0 \cdot 8$ & 0.7 & 120 & 70 & $8 \cdot 2$ & $8 \cdot 9$ \\
\hline 69 & 39 & $2 \cdot 6$ & $2 \cdot 2$ & 56 & 35 & $\mathbf{3 \cdot 9}$ & $4 \cdot 2$ \\
\hline
\end{tabular}

With no added molasses, seepage did not occur until after 12 days, when it rapidly increased. After 22 days large amounts of drained-off juice were yielded and the resulting total losses in 'dry matter' reached c. $9 \%$. At 69 days less juice was found than at 39 days, agreeing well with the previously mentioned less vigorous fermentation in the last bag. It cannot, however, be said whether, under practical conditions in the silo itself, more of the drainedoff juice would have appeared as seepage or would have been retained by the silage. The experiments of Steensberg (1945) showed that only small losses in dry matter were due to seepage. Under practical conditions the silage does not seem to release much water.

\section{CONCLUSION}

It has thus been possible to follow the fermentation processes in silage under practical conditions and to carry out many determinations during the course of the experiments, making chemical and bacteriological analyses.

Addition of molasses to sugar-beet pulp saved its 'dry-matter' content and diminished the number of butyric acid bacteria, thus giving a fodder rich 
in feeding units and suitable for milk production for cheese making. The addition of $40 \mathrm{~kg}$. molasses/metric ton pulp gave a silage with 35 units more feeding value as compared with silage made without added molasses (see

Table 5. Losses in 'dry-matter' through fermentation and in seepage

$\begin{array}{lcccc}\text { Losses } & \overbrace{\text { Pg./kg. } \times 10^{3}}^{\text {Percentage }} & \begin{array}{c}\text { of original } \\ \mathrm{kg} \cdot / \mathrm{kg} \cdot \times 10^{3}\end{array} & \begin{array}{r}\text { Percentage } \\ \text { of original }\end{array} \\ \text { By fermentation } & 0 & 0 & 6 \cdot 7 & 7 \cdot 6 \\ \text { In seepage } & 2 \cdot 6 & 2 \cdot 2 & 8 \cdot 2 & 8 \cdot 9 \\ \text { Total } & 2 \cdot 6 & 2 \cdot 2 & 14 \cdot 9 & 16 \cdot 5\end{array}$

Table 5). Assuming that $1.3 \mathrm{~kg}$. molasses has a feeding value of one feeding unit, the gain of feeding units in the molasses silage paid for the expense of the molasses used.

\section{REFERENCES}

Beynum, J. van \& Pette, J. W. (1935-6). Zuckervergärende und laktatvergärende Buttersäurebakterien. Zbl.Bakt. (2. Abt.), 93, 198.

ENEbo, L. (1943). Om termofil cellulosejäsning. Svensk kem. Tidskr. 55, 144.

Folin, O. (1902). Hoppe-Seyl. Z. 37, 161. (Quoted from Handb. d. Lebensm. chem., 1935, II/2, 646. Berlin: Springer.)

JARL, F. (1948). New investigations on the nutritive value of the by-products of sugar beet cultivation. Socker Handl. 4, 145.

Kullgren, C. \& Tydén, H. (1929). Über die Bestimmung von Pentosanen. Stockholm. (Quoted from Handb. d. Lebensm. chem. 1935, II/2, 932. Berlin: Springer.)

LEK, J. B. VAN DER (1930). Onderzoekingen over de butylalkoholgisting. Dissertation, Delft.

Olsen, E. (1949). Studies on the intestinal flora of infants. Thesis. Copenhagen: Munksgaard.

Orla-Jensen, S. (1919). The lactic acid bacteria. K. danske vidensk. Selsk. Skr. naturvidensk. og mathem. Afd. 8, 5, 79.

Orla-Jensen, S., Orla-Jensen, Anna D. \& Snog-KJar, Agnete (1948). Biological researches on the silage process. $K$. danske vidensk. Selsk. biol. Skr. 6, no. 1.

Osburn, O. L., Wood, H. G. \& Werkman, C. H. (1936). Determination of volatile fatty acids by the partition method. Industr. Engng. Chem. (Anal. ed.), 8, 270.

Parnas, J. (1912). Über das Schicksal der stereoisomeren Milchsäure im Organismus des normalen Kaninchens. Biochem. Z. 38, 53. (Quoted from Orla-Jensen et al. 1948.)

Peterson, W. H. \& Fred, E. B. (1932). Butyl-acetone fermentation of corn meal. Interrelations of substrate and products. Industr. Engng. Chem. 24, 237.

Richard, O. (1947). Die Beziehungen des beweglichen Buttersäurebazillus (Clostridium butyricum Praz.) zum Silofutter. 4th Int. Congr. Microbiol., Copenhagen, p. 522.

Richard, O. (1948). Variation in morphological and biochemical characteristics of anaerobic butyric acid bacteria. Nature, Lond., 162, 463.

ScharRer, K. \& Kürschner, K. (1931). Ein neues, rasch durchführbares Verfahren zur Bestimmung der Rohfaser in Futtermitteln. Biederm. Z Zbl. B. Tierernährung, 3, 302. (Quoted from Handb. d. Lebensm. chem. 1935, II/2, 944. Berlin: Springer.)

Sloep, A. C. (1928). Dissertation, Delft. (Quoted from Handb. d. Lebensm. chem. 1935, Ir/2, 944. Berlin: Springer.) 
Spengler, O., Tödt, F. \& Scheuer, M. (1936). Die Gesetzmässigkeiten bei der Reaktion von Invertzucker und Saccharose mit kupferhaltigen alkalischen Lösungen in der Wärme. Z. Wirt. Zuckerind., Techn. Teil, 86, 130, 322.

SteEnsBerg, V. (1945). Opbevaringsforsog med Sukkerroeaffald, p. 219. Copenhagen: Beretn. fra Forsøgslab.

SzeberĚnyi, P. (1917). Bestimmung der Milchsäure bei Gegenwart anderer organischen Säuren. Z. anal. Chem. 56, 505. (Quoted from Handb. d. Lebensm. chem. 1935, II/2, 1101. Berlin: Springer.)

(Received 17 August 1950) 